\title{
Interleukin 31 Measurement
}

National Cancer Institute

\section{Source}

National Cancer Institute. Interleukin 31 Measurement. NCI Thesaurus. Code C74829.

The determination of the amount of interleukin 31 present in a sample. 